\title{
PEMANFAATAN DATA WAREHOUSE DI PERGURUAN TINGGI INDONESIA
}

\author{
Iik Wilarso \\ Fakultas Ilmu Komputer, Universitas Indonesia, Depok, Indonesia \\ iik@cs.ui.ac.id
}

\begin{abstract}
Abstrak
Paradigma Baru Pendidikan Tinggi [1,2] yang dicanangkan oleh Direktorat Jenderal Pendidikan Tinggi pada tahun 1995, mengubah pola manajemen institusi pendidikan tinggi di Indonesia, dimana manajemen institusi pendidikan tinggi harus senantiasa melakukan evaluasi diri secara berkesinambungan guna peningkatan kualitas institusi tersebut dalam melaksanakan misi Tridharma Pendidikan Tinggi. Untuk dapat melakukan evaluasi diri diperlukan berbagai data dan informasi, baik data internal maupun eksternal institusi. Dengan melihat kebutuhan berbagai macam data dan informasi yang diperlukan untuk penyusunan laporan evaluasi diri, seharusnya dapat mendorong pemanfaatan teknologi data warehouse maupun data mining pada institusi tersebut. Pada kenyataannya, belum ada satupun institusi pendidikan tinggi di Indonesia yang memanfaatkan teknologi data warehouse maupun data mining untuk penyusunan laporan evaluasi diri. Hal ini disebabkan karena hampir semua institusi pendidikan tinggi di Indonesia belum mempunyai Sistem Informasi yang tertata dengan baik dan digunakan untuk pengelolaan manajemen institusi pendidikan tinggi pada semua jenjang atau tingkatan manajemen (institusi, fakultas, jurusan maupun program studi).
\end{abstract}

Kata kunci: data warehouse, pendidikan tinggi

\section{Pendahuluan}

\subsection{Paradigma Baru Pendidikan Tinggi}

Kerangka Pengembangan Pendidikan Tinggi Jangka Panjang (KPPT-JP) III 1995-2005 [1] yang disusun oleh Direktorat Jenderal Pendidikan Tinggi, menetapkan bahwa setiap institusi pendidikan tinggi di Indonesia dalam waktu 10 tahun, tahun 1995 sampai dengan 2005, harus menerapkan Paradigma Baru Pendidikan Tinggi sebagai salah satu upaya peningkatan kualitas institusi pendidikan tinggi tersebut.

Paradigma Baru Pendidikan Tinggi, pada dasarnya menggunakan pendekatan bottom up, yang bertumpu pada 5 (lima) pilar utama yaitu evaluasi, otonomi, akuntabilitas, akreditasi dan peningkatan kualitas berkesinambungan. Keterkaitan antar kelima pilar tersebut digambarkan dalam bentuk tetrahedron (lihat Gambar 1).

Berdasarkan KPPT-JP III [1], mulai tahun 1995, Direktorat Jenderal Pendidikan Tinggi membuat skema pendanaan institusi pendidikan tinggi yang didasarkan pada kompetisi dan pemberian dananya dilakukan secara blok (block grant). Direktorat Jenderal Pendidikan Tinggi mengkompetisikan beberapa proyek pengembangan dan pendanaan institusi pendidikan tinggi. Sampai dengan tahun 2008 telah ada 10 proyek pendanaan perguruan tinggi yang dikompetisikan, yaitu:

1. Development for Undergradute Education Project (DUE), 1995 - 2003, sumber dana Bank Dunia (World Bank).

2. Quality for Undergradute Education Project (QUE), 1997 - 2004, sumber dana Bank Dunia (World Bank).

3. DUE-like, 1999 - 2003, sumber dana APBN Pemerintah Indonesia.

4. Technical and Professional Skills Development Sector Project (TPSDP), 2001 2007, sumber dana Bank Pembangunan Asia (Asian Development Bank).

5. Semi-QUE, 1999 - 2004, sumber dana APBN Pemerintah Indonesia.

6. Program Hibah Kompetisi (PHK) 2003 - 2007, sumber dana APBN Pemerintah Indonesia.

7. Program Hibah Kompetisi (PHK) untuk Pendidikan Guru Sekolah Dasar (PHK-PGSD) 2006, sumber dana APBN Pemerintah Indonesia.

8. Sistem Perencanaan, Penyusunan Program dan Penganggaran (SP4), 2002 - 2006, sumber dana APBN Pemerintah Indonesia. 


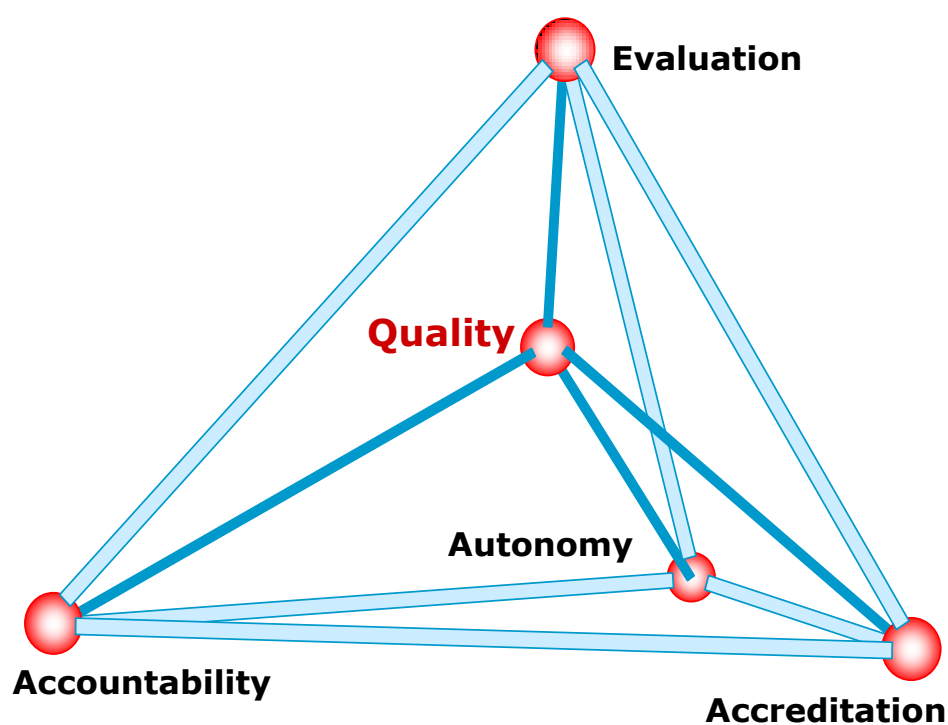

Gambar 1. Paradigma Baru Pendidikan Tinggi

9. Indonesia Managing Higher Education for Relevance Efficiency Project (IM-HERE), 2004 - 2009, sumber dana : Bank Dunia (World Bank).

10. Program Hibah Kompetisi Institusi (PHKI), 2008 sampai sekarang, sumber dana APBN Pemerintah Indonesia.

Untuk memperoleh dana hibah, institusi pendidikan tinggi (perguruan tinggi) harus menyusun proposal yang didasarkan atas hasil evaluasi diri (self-evaluation) institusi tersebut [3]. Hampir semua proyek tersebut diatas (kecuali Semi-QUE dan SP4), seleksi proposal dilakukan dalam 3 tahap, sebagai berikut:

1. Seleksi tahap pertama dilakukan terhadap Laporan Evaluasi Diri (Self-evalution Report) yang diajukan oleh perguruan tinggi peserta kompetisi. Apabila Laporan Evaluasi Diri dinyatakan baik, maka perguruan tinggi dinyatakan lulus untuk mengikuti seleksi tahap kedua dengan membuat proposal yang berisi usulan aktivitas pengembangan institusi yang didasarkan atas masalah yang berhasil diidentifikasi pada waktu melakukan Evaluasi Diri

2. Seleksi tahap kedua dilakukan terhadap Proposal yang diajukan perguruan tinggi. Apabila aktivitas yang diusulkan tersebut dinilai baik dan layak (feasible) untuk dilaksanakan, maka perguruan tinggi tersebut masuk pada tahap seleksi ketiga.

3. Seleksi tahap ketiga dilakukan dengan melakukan kunjungan ke perguruan tinggi yang mengajukan proposal untuk melihat secara langsung komitmen seluruh civitas academica untuk mensukseskan proyek hibah tersebut dan kesiapan perguruan tinggi untuk melaksanakan semua aktivitas yang diusulkan.

Untuk dapat menyusun Laporan Evaluasi Diri diperlukan berbagai macam data dan informasi yang ada di institusi pendidikan tinggi tersebut yang meliputi semua aspek yang terkait dengan misi yang diemban oleh intitusi tersebut, Tridharma Peruguruan Tinggi, yaitu Pendidikan, Penelitian dan Pengabdian Pada Masyarakat [4].

Selain untuk memperoleh dana hibah yang di kompetisikan, institusi pendidikan tinggi juga harus mengakreditasikan unit-unit satuan pendidikan (program studi) berbagai jenjang pendidikan dan juga institusinya sendiri. Akreditasi untuk institusi pendidikan tinggi dilakukan oleh Badan Akreditasi Nasional Perguruan Tinggi (BAN-PT) yang saat ini merupakan salah satu badan yang ada di lingkungan Departemen Pendidikan Nasional. Persyaratan untuk mendapatkan akreditasi dari BAN-PT, institusi pendidikan tinggi diwajibkan untuk mengisi borang akreditasi dan untuk dapat mengisi borang tersebut, diperlukan berbagai macam data dan informasi seperti yang diminta didalam penyusunan Laporan Evaluasi Diri.

Sebagai suatu organisasi yang mempunyai peran strategis didalam mencerdaskan bangsa, seharusnya setiap institusi pendidikan tinggi di Indonesia, seharusnya mempunyai Rencana Pengembangan Jangka Panjang yang menggambarkan arah pengembangan institusi pendidikan tinggi tersebut. Berdasarkan laporan dari Sekretaris Direktorat Jenderal Pendidikan Tinggi, tahun 2001 [5], hampir seluruh Perguruan Tinggi Negeri di Indonesia telah memiliki Rencana Pengembangan Jangka Panjang, 
namun pada kenyataannya, pelaksana pengembangan intitusi pendidikan tersebut tidak pernah mengacu pada Rencana Pengembangan Jangka Panjang yang telah disusunnya. Hal ini menunjukkan bahwa Rencana Pengembangan Jangka Panjang institusi pendidikan tinggi tersebut, disusun tidak berdasarkan data dan informasi yang ada didalam institusi pendidikan tinggi.

Kebutuhan akan data dan informasi tersebut diatas, tampaknya hanya bisa dipenuhi apabila institusi pendidikan tinggi telah memanfaatkan sistem informasi berbasis teknologi informasi dan menggunakan teknologi data warehouse sebagai sarana untuk melakukan berbagai analisa yang mendalam mengenai kondisi dan situasi institusi pendidikan tinggi tersebut.

\subsection{Sistem Informasi di Perguruan Tinggi}

Pada tahun 1990, Direktorat Jenderal Pendidikan Tinggi, telah merancang Sistem Informasi Nasional Pendidikan Tinggi (SINAS-DIKTI) yang terdiri dari :

1. Sistem Informasi Manajemen Direktorat Jenderal Pendidikan Tinggi

2. Sistem Informasi Manajemen Koordinator PTS (KOPERTIS)
3. Sistem Informasi Manajemen Peguruan Tinggi.

Rancangan yang dibuat, disusun dalam 3 kelompok dokumen, yaitu :

1. Rencana Induk Pengembangan SINASDIKTI, terdiri dari 1 buku [6].

2. Rancangan Global SINAS-DIKTI, terdiri dari 4 buku [7].

3. Rancangan Detail SINAS-DIKTI, terdiri dari 12 buku [8].

Sistem Informasi Manajermen Perguruan Tinggi (SIM-PT) terdiri dari 10 subsistem, sebagai berikut :

1. Subsistem Akademik atau Subsistem Pendidikan.

2. Subsistem Penelitian.

3. Subsistem Pengabdian Pada Masyarakat.

4. Subsistem Kemahasiswaan dan Alumni

5. Subsistem Ketenagaan atau Subsistem Personalia

6. Subsistem Keuangan.

7. Subsistem Kerjasama Lembaga

8. Subsistem Sarana \& Prasarana

9. Subsistem Perpustakaan

10. Susbsistem Manajemen atau Executive Information System (EIS).

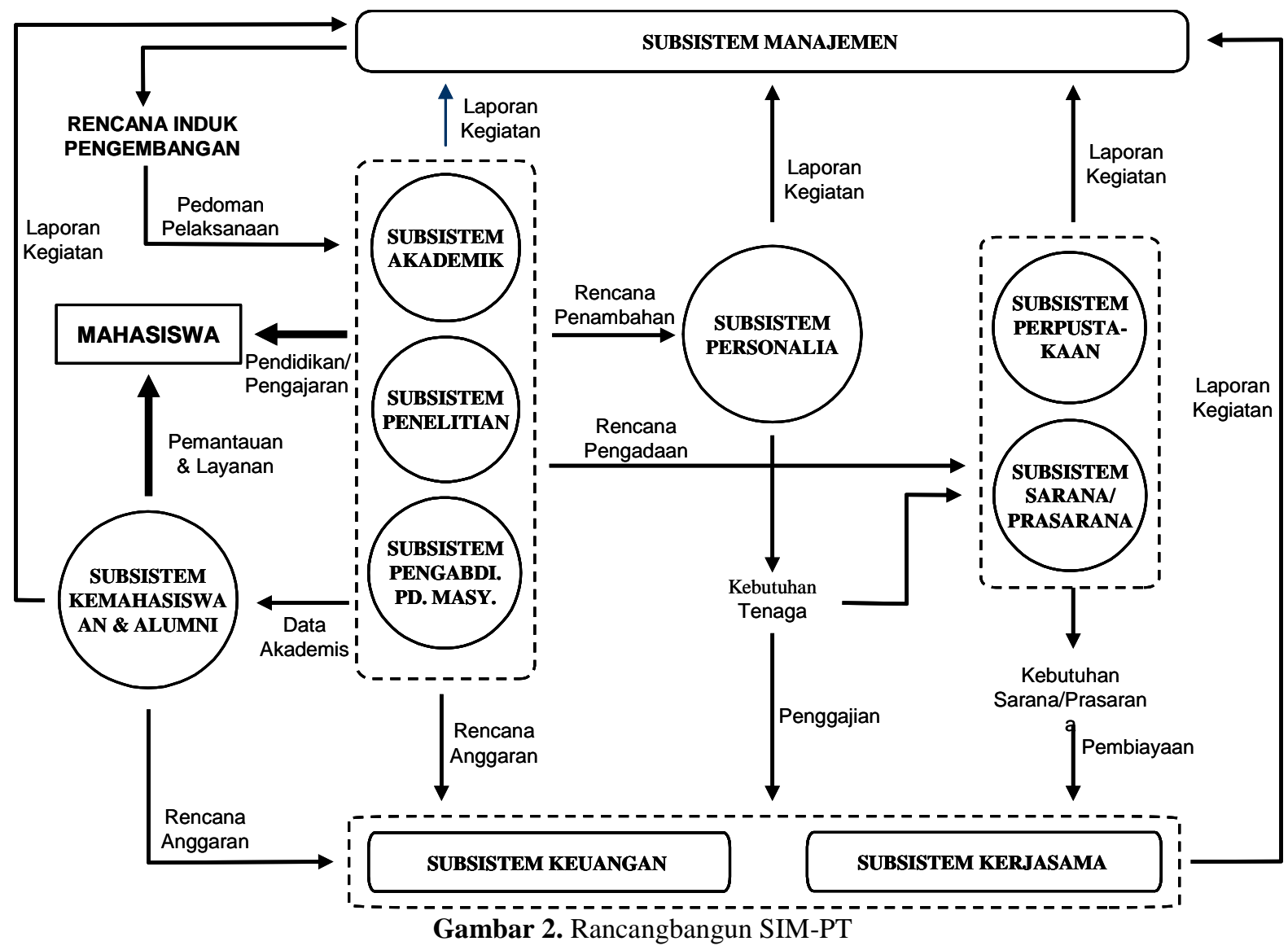


Pada rancang bangun SIM-PT yang menggambarkan kaitan antar subsistem diperlihatkan secara garis besar pada Gambar 2. Dari 10 susbsistem tersebut diatas, subsistem nomor 1 sampai nomor 9, telah selesai dibuat aplikasinya dan diujicobakan di Universitas Negeri Sebelas Maret (UNS). Aplikasi yang telah dibuat tersebut diberikan secara gratis kepada PTN atau PTS yang membutuhkan.

Berdasarkan hasil review dan pengamatan pada waktu kunjungan yang dilakukan sejak tahun 1996 sampai dengan 2006 pada lebih dari 50 perguruan tinggi, baik PTN maupun PTS, yang mengajukan proposal hibah kompetisi melalui berbagai skema pendanaan yang ada di Direktorat Jenderal Pendidikan Tinggi, belum ada satupun perguruan tinggi yang mengimplementasikan SINAS-DIKTI secara keseluruhan dan hanya $50 \%$ yang telah mempunyai dan memanfaatkan sistim informasi. Umumnya, subsistem yang telah diimplementasi perguruan tinggi adalah subsistem akademik, subsistem ketenagaan atau personalia dan subsistem perpustakaan.

Direktorat Jenderal Pendidikan Tinggi pada tahun 2006 telah berhasil membangun jaringan komputer antar perguruan tinggi yang dinamakan INHERENT, singkatan dari Indonesian Higher Education Network. Dengan adanya INHERENT, Direktorat Jenderal Pendidikan Tinggi juga memberikan dana hibah kompetisi untuk pengembangan Teknologi Informasi dan Komunikasi (TIK) di perguruan tinggi, yang terdiri 3 jenis, yaitu :

1. Program Hibah Kompetisi Pengembangan Kegiatan dan Konten (K-1).

2. Program Hibah Kompetisi Peningkatan Kapasitas Institusi dalam TIK, bagi PTN (K-2).

3. Program Hibah Kompetisi Peningkatan Kapasitas Institusi dalam TIK, bagi PTS (K$3)$.

Usulan untuk pengembangan Sistem Informasi Manajemen masuk pada program K-2 dan K-3. Pada tahun 2008, hibah yang ditawarkan hanya K-1 dan K3 , berarti bahwa seluruh Perguruan Tinggi Negeri telah dinilai mempunyai kapasitas untuk memanfaatkan TIK dalam kegiatan operasionalnya.

Berdasarkan hasil review yang dilakukan pada lebih dari 20 proposal hibah TIK K-1, tidak ada satupun proposal yang mengajukan proposal untuk pengembangan data warehouse, yang paling banyak usulan untuk pengembangan konten pembelajaran dengan memanfaatkan e-Learning. Dengan demikian dapat disimpulkan bahwa pemanfaatan TIK di perguruan tinggi di Indonesia, lebih fokus untuk membantu proses pembelajaran dari pada proses manajemen perguruan tinggi.

\section{Kebutuhan Informasi Institusi Pendidikan Tinggi}

Paradigma Baru Pendidikan Tinggi mengubah beberapa pola pikir dan memperkenalkan isu-isu strategis dalam manajemen institusi pendidikan tinggi. Ada beberapa isu strategis penting yang harus dikelola oleh institusi pendidikan tinggi, agar tercapai apa yang disebut sebagai kesehatan organisasi (organization health). Isu strategis tersebut dikenal sebagai RAISE, yang merupakan singkatan dari :

1. Relevance (relevansi).

Relevansi merupakan cerminan dari tingkat sensitivitas institusi pendidikan tinggi terhadap lingkungan di mana institusi tersebut berada.

2. Academic Atmosphere (suasana akademik)

Suasana akademik merupakan suasana yang menggambarkan tata hubungan yang sehat antar civitas academica pada institusi pendidikan tinggi, sehingga memacu motivasi dan kreativitas di kalangan civitas academica dalam menjalankan kegiatan akademik.

3. Internal Management and Organization (organisasi dan manajemen internal).

Bentuk organisasi dan sistem manajemen institusi pendidikan tinggi sangat berperan dalam peningkatan kesehatan organisasi. Sistem manajemen di institusi pendidikan tinggi sangat berbeda dengan sistem manajemen yang ada di organisasi bisnis pada umumnya, dimana lebih mengedepankan pola hubungan kolegial antara jajaran struktural dengan staf akademik.

4. Sustainability (keberlanjutan atau keberlangsungan).

Aspek keberlanjutan pada institusi pendidikan tinggi terdiri dari 3 aspek, yaitu (1) aspek keberlanjutan yang menjamin eksistensi institusi, (2) aspek keberlanjutan yang menjamin tingkat kualitas yang telah dicapai melalui program pengembangan dan (3) aspek keberlanjutan atas sumberdaya yang telah diadakan (invested resources).

5. Efficiency and Productivity (efisiensi dan produktivitas).

Secara sederhana efisiensi dapat diartikan sebagai tingkat kehematan dalam pemanfaatan sumber daya, sedangkan produktivitas diartikan sebagai tingkat kemampuan untuk menghasilkan keluaran sesuai dengan masukan dan proses yang ditetapkan

Untuk mendapatkan gambaran mengenai ke 5 isu strategis diperlukan evaluasi diri yang komprehensif dan melibatkan semua pihak yang terkait, baik internal maupun eksternal. Selain kedua hal tersebut, kualitas hasil evaluasi diri juga sangat ditentukan 
oleh keakuratan data dan informasi yang digunakan sebagai basis analisa dan proses analisa yang mendalam (depth of analysis).

Proses evaluasi untuk pengembangan institusi pendidikan tinggi sangat berbeda dengan proses evaluasi untuk akreditasi. Proses evaluasi untuk pengembangan institusi pada dasarnya sama seperti proses evaluasi untuk penyusunan rencana strategis, sedangkan evaluasi untuk akreditasi lebih pada proses membandingkan profil dan kinerja institusi pendidikan tinggi dengan profil dan kinerja standar yang telah ditetapkan untuk akreditasi.

Institusi pendidikan tinggi dalam melakukan evaluasi diri yang berkaitan dengan aspek internal, harus melakukan 2 jenis evaluasi, yaitu (1) Evaluasi Program Akademik (pendidikan, penelitian dan pengabdian pada masyarakat) dan (2) Evaluasi Tata Pamong (governance) pada semua tingkatan manajemen (insitusi, fakultas, jurusan, program studi) di lingkungan institusi tersebut.

Evaluasi program akademik yang terkait dengan proses pendidikan memerlukan berbagai jenis data mahasiswa, mulai dari kualitas mahasiswa baru (kualitas input) sampai dengan kinerja lulusan dalam bekerja (kualitas outcome). Data dan informasi proses pembelajaran merupakan titik sentral yang perlu dikaji dan dianalisa untuk menentukan tingkat keberhasilan dalam pelaksanaan dharma pendidikan. Disadari sepenuhnya bahwa keberhasilan lulusan institusi pendidikan tinggi dalam bermasyarakat tidak semata-mata hanya dari proses pembelajaran yang dilaksanakan sesuai dengan kurikulum yang telah ditetapkan, namun juga kegiatan ekstrakurikuler yang sangat berperan dalam peningkatan kualitas soft skills lulusan (logical skills, analytical skills communications skills, mampu bekerja secara team, dsb). Perhatian pada soft skills lulusan, pada 5 tahun terakhir mengalami peningkatan, karena dari beberapa studi diketahui bahwa soft skills lulusan merupakan salah satu faktor penentu keberhasilan lulusan dalam bermasyarakat. Pengguna lulusan (employer), pada kondisi persaingan bisnis global yang dihadapi saat ini, ada kecenderungan untuk lebih mementingkan soft skills dari pada penguasaan ilmu dan teknologi (hard skills) dalam mengangkat pegawai.

Evaluasi program akademik yang terkait dengan dharma penelitian dan pengabdian pada masyarakat memerlukan berbagai data dari civitas academica, terutama staf pengajar atau staf akademik, mulai dari bidang keilmuan yang dikuasai (kepakaran) sampai dengan kinerja dari staf akademik tersebut. Data dan informasi yang terkait dengan kinerja dari staf akademik pada dharma penelitian dan dharma pengabdian masyarakat, tidak mudah diperoleh mengingat bahwa staf akademik dalam berkarya di dalam institusi maupun di masyarakat, sifatnya sangat independen.

Evaluasi Tata Pamong pada institusi pendidikan tinggi, selain melakukan evaluasi terhadap tata kelola institusi pendidikan tinggi secara menyeluruh, juga pada pengelolaan berbagai sumberdaya yang ada. Sumberdaya institusi pendidikan tinggi, sangat bervariasi dan bergantung dengan bidang keilmuan yang ada didalam institusi tersebut. Setiap bidang keilmuan, memiliki sumberdaya yang sangat spesifik, termasuk jenis staf akademik, sarana laboratorium maupun kepustakaan. Laboratorium yang dimiliki suatu bidang keilmuan juga sangat beragam, termasuk juga laboratorium lapangan (field laboratorium) yang umumnya lokasinya terletak di luar institusi tersebut. Namun demikian, manajemen sumberdaya institusi pendidikan tinggi dapat dikelompokkan menjadi 4 manajemen sebagai berikut:

1. Manajemen Keuangan

2. Manajemen Sumberdaya Manusia.

3. Manajemen Fasilitas Fisik, terdiri dari:
a. Manajemen Prasarana (Gedung / Bangunan)
b. Manajemen Laboratorium.
c. Manajemen Perpustakaan.

4. Manajemen Data dan Informasi

Selain evaluasi untuk program akademik dan tata pamong, juga dilakukan evaluasi terhadap sistem penjaminan mutu yang ada di institusi pendidikan tersebut. Evaluasi ini perlu dilakukan, karena berkaitan dengan salah satu aspek dari isu strategis sustainability. Evaluasi yang dilakukan lebih menitikberatkan pada proses penjaminan mutu dan proses updating standar mutu yang digunakan. Sistem Penjaminan Mutu di institusi pendidikan tinggi, diintensifkan pelaksanaanya oleh Direktorat Jenderal Pendidikan Tinggi sejak tahun 2006. Untuk institusi pendidikan tinggi yang telah memperoleh hibah, diwajibkan untuk membangun dan mengimplementasikan Sistem Penjaminan Mutu Akademik.

\section{Pemanfaatan Data Warehouse di Institusi Pendidikan Tinggi}

Untuk melihat sejauh mana pengembangan dan pemanfaatan data warehouse pada institusi pendidikan tinggi, di Indonesia digunakan Universitas Indonesia (UI) sebagai studi kasus [9] dan sebagai pembanding adalah Florida State University (FSU) [10] yang telah membangun dan memanfaatkan data warehouse yang relatif cukup lengkap. 
Tabel 1. Tabel dimensi

\begin{tabular}{|c|l|l|}
\hline No. & \multicolumn{1}{|c|}{ Tabel Dimensi } & \multicolumn{1}{c|}{ Keterangan } \\
\hline 1 & Dim_Time & Data dimensi waktu : semester dan tahunan \\
\hline 2 & Dim_Organisasi & Data dimensi organisasi : universitas, fakultas, jurusan \& PS \\
\hline 3 & Dim_Student & Data dimensi mahasiswa : identitas mahasiswa \\
\hline 4 & Dim_St_Akademik & Data dimensi status akademik : aktif, cuti, DO, lulus, dsb \\
\hline 5 & Dim_Range_Nilai & Data dimensi skala indeks prestasi kumulatif (IPK) \\
\hline 6 & Dim_Jalur_Masuk & Data dimensi jalur masuk UI : SPMB, PPKB, Pedati, dsb \\
\hline 7 & Dim_Gender & Data dimensi jenis kelamin : Laki-laki \& Perempuan \\
\hline 8 & Dim_Dosen & Data dimensi dosen : identitas dosen \\
\hline 9 & Dim_Jenjang & Data dimensi jenjang pendidikan : Diploma, S1, S2, S3, dsb \\
\hline 10 & Dim_Range_Umur & Data dimensi umur untuk pengelompokan umur \\
\hline 11 & Dim_Status_Pegawai & Data dimensi status kepegawaian dosen. \\
\hline
\end{tabular}

Tabel 2. Tabel fakta

\begin{tabular}{|c|c|c|}
\hline No. & Tabel Fakta & Keterangan/Penggunaan \\
\hline 1 & DWH_STATUS_MAHASISWA_SEM & $\begin{array}{l}\text { Ringkasan status [Mendaftar, Cuti, Keluar, Dikeluarkan, Lulus] } \\
\text { mahasiswa (menurut tahun) }\end{array}$ \\
\hline 2 & DWH_STATUS_MAHASISWA_THN & $\begin{array}{l}\text { Ringkasan status [Mendaftar, Cuti, Keluar, Dikeluarkan, Lulus] } \\
\text { mahasiswa (menurut semester) }\end{array}$ \\
\hline 3 & DWH_REG_MHS & $\begin{array}{l}\text { Jumlah daya tampung, peminat, diterima, dan mendaftar di UI } \\
\text { (menurut tahun) }\end{array}$ \\
\hline 4 & DWH_MTTW_SEM & $\begin{array}{l}\text { Jumlah mahasiswa UI yang tidak lulus tepat waktu (menurut } \\
\text { semester) }\end{array}$ \\
\hline 5 & DWH_MTTW_THN & Jumlah mahasiswa UI yang tidak lulus tepat waktu (menurut tahun) \\
\hline 6 & DWH_ENROL_SEM & $\begin{array}{lcccc}\text { Statistik Penilaian } & \text { Kuliah Mahasiswa per } & \text { PS/Jurusan/ } \\
\text { Fakultas/Universitas, per MK (menurut semester) } & & \\
\end{array}$ \\
\hline 7 & DWH_ENROL_THN & $\begin{array}{l}\text { Statistik Penilaian Kuliah Mahasiswa per } \\
\text { Fakultas/Universitas, per MK (menurut semester) }\end{array}$ \\
\hline 8 & DWH_ENROL & $\begin{array}{lllll}\text { Statistik Penilaian Kuliah } & \text { Mahasiswa } & \text { per } & \text { PS/Jurusan/ } \\
\text { Fakultas/Universitas, per MK (keseluruhan) } & & \\
\end{array}$ \\
\hline 9 & DWH_MENGAJAR_SEM & $\begin{array}{l}\text { Statistik Rata-rata Jumlah Kelas Mata Kuliah per Pengajar per } \\
\text { jenjang (menurut semester) }\end{array}$ \\
\hline 10 & DWH_MENGAJAR_THN & $\begin{array}{l}\text { Statistik Rata-rata Jumlah Kelas Mata Kuliah per Pengajar per } \\
\text { jenjang (menurut tahun) }\end{array}$ \\
\hline 11 & DWH_MENGAJAR & $\begin{array}{l}\text { Statistik Rata-rata Jumlah Kelas Mata Kuliah per Pengajar per } \\
\text { jenjang (menurut tahun) }\end{array}$ \\
\hline 12 & DWH_JENIS_PEG & $\begin{array}{l}\text { Statistik Jumlah Pegawai UI (menurut tahun) per jenis pegawai } \\
\text { (keseluruhan) }\end{array}$ \\
\hline 13 & DWH_PANGKAT_PEG & Statistik Jumlah Pegawai UI berdasarkan Pangkat \\
\hline 14 & DWH_EVAL_MHS_SEM & Statistik Hasil Evaluasi Dosen oleh Mahasiswa (menurut semester) \\
\hline 15 & DWH_EVAL_MHS_THN & Statistik Hasil Evaluasi Dosen oleh Mahasiswa (menurut semester) \\
\hline 16 & DWH_EVAL_MHS & Statistik Hasil Evaluasi Dosen oleh Mahasiswa (keseluruhan) \\
\hline 17 & DWH_KOLEKSI_PERP_BHS & Statistik Jumlah Koleksi Perpustakaan (menurut bahasa) \\
\hline 18 & DWH_KOLEKSI_PERP & Statistik Jumlah Koleksi Perpustakaan (keseluruhan) \\
\hline 19 & DWH_PATRON_BLN & Statistik Jumlah Pengunjung Perpustakaan (menurut bulan) \\
\hline 20 & DWH_PATRON_THN & Statistik Jumlah Pengunjung Perpustakaan (menurut tahun) \\
\hline 21 & DWH_JUMLAH_BUKU_PINJAM & Statistik Jumlah Buku perpustakaan yang dipinjam (menurut tahun) \\
\hline 22 & DWH_JUMLAH_PEMINJAM & Statistik Jumlah Peminjam Buku perpustakaan (menurut tahun) \\
\hline 23 & DWH_RUANG & Statistik Jumlah Ruang berdasarkan jenis ruangan \\
\hline 24 & DWH_PUBLIKASI & Statistik Jumlah Publikasi Nasional dan Internasional \\
\hline 25 & DWH_NILAI_GRANT & Statistik Jumlah Total dana penelitian yang diperoleh \\
\hline 26 & DWH_UKM & $\begin{array}{l}\text { Statistik Jumlah Kegiatan dan Jumlah Anggota Unit Kegiatan } \\
\text { Mahasiswa }\end{array}$ \\
\hline
\end{tabular}


Universitas Indonesia (UI) sebagai salah satu perguruan tinggi terkemuka di Indonesia, baru tahun 2007 mulai mengembangankan data warehouse untuk menunjang proses pengambilan keputusan. Sampai saat ini data warehouse yang dikembangkan masih fokus pada aspek dharma pendidikan, karena sistem informasi yang sudah diimplementasikan dengan cukup lengkap dan digunakan secara intensif baru Sistem Informasi Akademik dan Kemahasiswaan (SIAK). Sistem informasi lainnnya, seperti Sistem Informasi Kepegawaian (SIPEG), Sistem Informasi Perpustakaan (LONTAR), Sistem Informasi Manajemen Aset Fasilitas (SIMAF), Sistem Informasi Keuangan, masih belum dikembangkan secara lengkap dan terintegrasi. Sistem informasi selain SIAK, yang sudah diimplementasikan dan digunakan, semua yang berkaitan dengan proses pendidikan dengan tujuan agar SIAK berfungsi dengan baik. SIPEG adalah sistem informasi terlengkap kedua setelah SIAK, namun implementasinya belum berjalan dengan baik, terutama yang terkait dengan kinerja staf akademik dalam kegiatan penelitian dan pengabdian pada masyarakat. LONTAR, nama sistem informasi perpustakaan, yang dikembangkan oleh Fakultas Ilmu Komputer UI, dinilai cukup lengkap dan telah digunakan dengan baik pada beberapa perpustakaan dilingkungan UI dan beberapa perpustakaan pada perguruan tinggi lain.

Awalnya pengembang sistem informasi di UI sebagian besar dilakukan oleh Unit Pelaksana Teknis Komputer (UPT Komputer), yang pada tahun 2003 berubah menjadi Unit Pengembang dan Pengelola Sistem Informasi (PPSI). Selain mengembangkan sistem informasi, UPT Komputer UI juga mengembangan jaringan kampus (campus network) yang menghubungkan kampus Salemba dengan kampus Depok dan menghubungkan semua fakultas dengan rektorat beserta unit-unit pusat (LPM, LPPM, UPT Perpustakaan, dsb). Setelah UI berubah status menjadi Badan Hukum Milik Negara (BHMN), struktur organisasi UI mengalami banyak perubahan.

Dilihat dari arsitektur, kondisi dan pengelolaan perangkat keras (hardware), perangkat keras teknologi informasi dan komunikasi di UI untuk mendukung pengoperasian SIM-PT dan juga pengembangan serta pengoperasian data warehouse, dinilai cukup memadai.

Dalam awal pengembangan data warehouse di UI tahun 2007, tabel fakta (fact tables) yang dikembangkan baru 3, yaitu :

1. Tabel fakta grade, yang digunakan untuk analisa dan pelaporan hal-hal yang terkait dengan prestasi akademik mahasiswa,
2. Tabel fakta pendaftaran, yang digunakan untuk analisa dan pelaporan hal-hal yang terkait dengan kualitas mahasiswa baru,

3. Tabel fakta lecturer, yang digunakan untuk analisa dan pelaporan hal-hal yang terkait dengan status dosen pada proses pembelajaran.

Tabel dimensi (dimension tables) yang disusun yang terkait dengan tabel fakta sebanyak 11 buah (lihat pada Tabel 1).

Dari tinjauan pada pertengahan tahun 2008, tabel fakta yang dikembangkan telah mencapai 26 buah dengan melibatkan 19 tabel dimensi. Perbedaan yang tampak dengan kondisi awal adalah adanya perubahan penamaan tabel, namun secara substansi tabel yang telah dikembangkan di awal tidak mengalami perubahan yang cukup significant (lihat Tabel 2).Tabel dimensi yang baru adalah (1) tabel dimensi mata kuliah, (2) tabel dimensi ruang, (3) tabel dimensi jenis ruang, (4) tabel dimensi golongan pegawai, (5) tabel dimensi jenis koleksi perpustakaan, (6) tabel dimensi bahasa, (7) tabel dimensi barang dan (8) tabel dimensi nama ukm.

Berdasarkan pengamatan, perkembangan jumlah tabel fakta yang ada di dalam data warehouse UI, sejalan dengan pemanfaatan aplikasi dari subsistem SIM-PT. Tabel fakta nomor 14 sampai dengan nomor 16, terkait dengan aplikasi EDOM (Evaluasi Dosen Oleh Mahasiswa) yang mulai dioperasionalkan Semester 1 tahun akademik 2007/2008.

Data warehouse di Florida State University (FSU), terdiri dari 5 data mart, yaitu (1) data pegawai (employee data), (2) data keuangan (financial data), (3) data laporan resmi institusi (official reporting data), (4) data mahasiswa (students data) dan (5) data pendaftaran (enrollment data). Berdasarkan informasi yang ada pada website data warehouse FSU, tampak bahwa data warehouse di FSU sudah diimplementasi dan digunakan dengan baik. Data dalam data warehouse tersebut dapat diakses secara terbuka oleh seluruh civitas academica FSU dari dalam dan luar kampus FSU. Informasi yang ada di website FSU, terdiri dari (1) tabel fakta yang digambar dengan star schema dan (2) tabel dimensi, (3) petunjuk cara menggunakan data warehouse, (4) security data dan informasi lainnya.

Apabila data warehouse yang ada di UI dibandingkan dengan data warehouse yang ada di FSU, tampak adanya perbedaan yang sangat mencolok. Yang tampak jelas adalah bahwa data warehouse di UI sifatnya masih tertutup, sedangkan di FSU sudah terbuka dan dapat diakses oleh civitas academica FSU atau pihak-pihak yang terkait yang membutuhkan data FSU. Perbedaan lain, FSU sudah membagi data warehouse menjadi beberapa data 
mart, sedangkan di UI, pembagian data warehouse ke dalam data mart belum tampak jelas.

\section{Kesimpulan}

Perkembangan pemanfaatan teknologi data warehouse di institusi pendidikan tinggi Indonesia jauh tertinggal dengan institusi pendidikan tinggi di beberapa negara maju seperti Amerika. Masalah utama yang menghambat adalah institusi pendidikan tinggi di Indonesia belum banyak yang memanfaatkan sistem informasi yang berbasis teknologi informasi dan komunikasi (TIK) untuk mendukung pengelolaan institusinya. Tanpa adanya sistem informasi yang digunakan untuk membantu pengelolaan institusi, maka teknologi data warehouse tidak mungkin dapat dikembangkan.

Perkembangan pemanfaatan sistem informasi untuk mendukung pengelolaan institusi pendidikan tinggi di Indonesia sangat memprihatinkan, walaupun Direktorat Jenderal Pendidikan Tinggi telah memperkenalkan dan membuatkan rancang bangun SIM-PT sejak tahun 1990. Kebutuhan untuk memanfaatkan sistem informasi di kalangan institusi pendidikan tinggi Indonesia, mulai tampak sejak Direktorat Jenderal Pendidikan Tinggi menerapkan Paradigma Baru Pendidikan Tinggi dan memberikan bantuan dana hibah ke institusi pendidikan tinggi dengan secara kompetisi. Usaha Direktorat Jenderal Pendidikan Tinggi untuk mendorong agar pengelola institusi pendidikan tinggi memanfaatkan sistem informasi akan lebih digalakkan dengan adanya hibah TIK dan semua usulan rencana pengembangan yang tercantum dalam proposal hibah harus merujuk ke rencana pengembangan jangka panjang institusi tersebut. Oleh karena itu, semua proposal hibah yang diajukan untuk tahun 2009 mendatang, wajib melampirkan rencana pengembangan jangka panjang institusi pendidikan tinggi tersebut.

\section{REFERENSI}

[1] Kerangka Pengembangan Pendidikan Tinggi Jangka Panjang III (1996-2005), Direktorat Jenderal Pendidikan Tinggi, 1995, dipublikasikan di lingkungan internal dan perguruan tinggi.
[2] Kerangka Pengembangan Pendidikan Tinggi Jangka Panjang IV (2003-2010), Direktorat Jenderal Pendidikan Tinggi, 2002, dipublikasikan di lingkungan internal dan perguruan tinggi.

[3] Guidelines for Subproject Proposal Batch III Technological And Professional Skills Development Sector Project, Directorate General of Higher Education Ministry of National Education, 2003, dipublikasi ke semua perguruan tinggi di Indonesia.

[4] Panduan Penyusunan Laporan Evaluasi Diri Program Hibah Kompetisi 2005, Dewan Pendidikan Tinggi, Direktorat Jenderal Pendidikan Tinggi, 2004, dipublikasi ke semua perguruan tinggi di Indonesia.

[5] Laporan Tahun Direktorat Jenderal Pendidikan Tinggi Tahun 2001, Direktorat Jenderal Pendidikan Tinggi, 2001, dipublikasikan internal.

[6] Rencana Induk Pengembangan Sistem Informasi Nasional Pendidikan Tinggi (SINAS-DIKTI), Direktorat Jenderal Pendidikan Tinggi, 1989, dipublikasikan internal.

[7] Rancangan Global Sistem Informasi Nasional Pendidikan Tinggi (SINAS-DIKTI), Direktorat Jenderal Pendidikan Tinggi, 1990, dipublikasikan internal.

[8] Rancangan Detail Sistem Informasi Nasional Pendidikan Tinggi (SINAS-DIKTI), Direktorat Jenderal Pendidikan Tinggi, 1991, dipublikasikan internal.

[9] Setyo Kuncoro, Perancangan Data Warehouse untuk menunjang Sistem Informasi Eksekutif Pendidikan Universitas Indonesia, Thesis Program Studi Magister Teknologi Informasi Fakultas Ilmu Komputer Universitas Indonesia, 2007.

[10] Data Warehouse Florida State University, http://www.oti.fsu.edu/dba/welcome.html. 